\title{
"Spirituality" as Privatized Experience-Oriented Religion: Empirical and Conceptual Perspectives
}

\author{
HEINZ STREIB ${ }^{1}$ AND RALPH W. HOOD ${ }^{2}$ \\ ${ }^{1}$ Research Centre for Biographical Studies in Contemporary Religion \\ Universität Bielefeld \\ ${ }^{2}$ Psychology Department, University of Tennessee at Chattanooga
}

Heinz.streib@uni-bielefeld.de; Ralph-Hood@utc.edu

\begin{abstract}
Recent empirical studies demonstrate that a growing number of people contrast "spirituality" and "religion," self-identifying as "spiritual, but not religious" or as "more spiritual than religious." This shift in everyday semantic preference, from "religion" to "spirituality," has also affected the terminology of the scientific study of religion, producing some uncertainty and ambivalence regarding the conceptualization of spirituality. This is critically discussed. To inspire reflection, the article refers to some classics in philosophy, psychology and sociology of religion. The aim is twofold: first, to take the self-description "spiritual" very seriously, and inspire more thoroughgoing and sophisticated research; second, to call into question the necessity of conceptualizing 'spirituality' and to suggest that the concept of 'religion' is sufficient, because "spirituality" can be understood as privatized, experience-oriented religion.

Keywords

spirituality, mysticism, religion, James, Schleiermacher, Weber, Troeltsch

No one in the scientific study of religion can ignore the spectacular increase in popularity which self-identification as "being spiritual" enjoys these days. Of course, a majority of people in the United States and a considerable number in Europe use "spirituality" in association with "religion" (Hood, Hill and Spilka 2009; Streib 2008). But an apparently growing number of people contrast "spirituality" and "religion," self-identifying as "spiritual, but not religious," or as "more spiritual than religious."
\end{abstract}


This relatively new shift in the everyday semantic preference from "religion" to "spirituality," has already affected the terminology of the scientific study of religion. Psychologists of religion, for example, have engaged in renaming their field (Hathaway et al. 2004). A growing number of authors use "religion" and "spirituality" side by side or use a slash between these words; many have already exchanged "religion" for "spirituality." Especially in areas such as health, articles are now more likely to refer to "spirituality" rather than to "religion" (Miller and Thoresen 2003). Scientists' new preference for "spirituality" could be understood simply as a reaction to changes in the everyday language of their research participants; but perhaps there are also other reasons.

The scientists' widespread sympathy for "spirituality" may be understood as part of an empirically documented gap between professionals and the larger lay public with respect to religious commitment. It is empirically documented that mental health professionals are among the least religious persons, and this could be the reason for their preference instead to identify with spirituality. Focusing primarily on samples of clinical and counseling psychologists who are members of the American Psychological Association, Shafranske (1996) notes that psychologists are less likely to believe in a personal God, or to affiliate with religious groups, than other professionals or the general population. While the majority of psychologists report that spirituality is important to them, a minority report that religion is important to them (Shafranske 1996, 153). Psychologists neither believe, practice, nor associate with the institutional aspects of faith ("religion") as much as they endorse what Shafranske $(1996,154)$ properly notes are "noninstitutional forms of spirituality."

There is, however, a qualitative difference between the semantic preference for "spirituality" by the "people on the street" who are or become our research participants, on the one hand, and scientists'/researchers' exchange of "religion" for "spirituality," on the other hand. While the former do not - and need not-engage in reflection on and justification of their terminology, the latter are required to reflectively care for their (system of) concepts and define them in respect to the most excellent thinkers in their scientific field. Viewed from this perspective, one may be surprised about the easiness of putting a concept ("religion") into the background-and with it a centuries-long scientific debate.

Thus, we wish to engage in serious reflection about concepts, and, in order to make a contribution to the debate, we conclude this article with an explication of our own conceptual proposal-which is conservative in

(C) Equinox Publishing Ltd. 2011 
the sense of pleading for "religion" as a general and comprehensive concept, of which de-institutionalized "spirituality" is a subdivision. To argue for and arrive at our conclusion, we first look at some empirical examples of de-institutionalized "spirituality,"We then critically discuss attempts to define "spirituality" or what we term privatized religion. Finally, we briefly refer to selected "classics" in the conceptualization of "religion" to support our conceptual proposal.

\section{Discovering and documenting "spirituality"}

To profile the preference for a "spiritual" self-identification in opposition to religion and to discuss the question whether we have a completely new phenomenon here, we should look at some older studies.

At the psychological level, Day, in his Sierra Project (which was specifically designed to advance students' stages of moral development), uncovered the dissatisfaction of many with a religious rather than a spiritual self-identification. A crucial aspect of this study (and its continuation since 1987 by researchers associated with Boston University) is the use of both traditional empirical and narrative-based qualitative methodologies (Whiteley and Loxley 1980; Day 1991, 1994). Day (1994) wrote up the results of an interview with one participant, "Sandy," in an idiographic presentation rare in psychology. The interview probed Sandy's views on both religion and spirituality - a tactic based upon researchers' belated recognition that earlier Sierra participants might have purposefully avoided discussion of religion, especially religious beliefs (Day 1994, 160). Thus questions on religion and spirituality were strategically placed within the schedule in subsequent interviews. Sandy took great care to distinguish religion from spirituality. In her words,

Religion is organized, dogmatic, and social. Spiritual is individual, intimate, personal. Religion tells you what is good or true and tells you who is favored and who is not. It operates in fixed categories. Spirituality is developed. You have to work hard at it and to be conscious about it and take time for it. Sometimes, in order to grow spiritually, you have to go beyond or even against religious doctrine. (163)

Sandy's concern with doctrine was important. Day noted that she would probably protest if identified as a "believer." She neither identified herself, nor wanted others to label her, as "religious" (Day 1994, 165).

At the sociological level, Roof (1993) has characterized the 76 million U.S. adults born in the two decades after World War II as a "generation of seekers" who are either "loyalists" (those who have stayed with their religious

(C) Equinox Publishing Ltd. 2011

\section{equinoxonline}


tradition), "returnees" (those who experimented with options, before returning to their religious tradition), or "dropouts" (those who have left their tradition). Roof also noted that a distinguishing feature among the "highly active seekers" he interviewed was a preference to identify themselves as "spiritual" rather than "religious." Twenty-four percent of these had no religious affiliation. Such highly active seekers were but a minority (9\%) of all Roof's participants, but they seem to have captured the interest of researchers in what we might describe, with Houtman and Aupers (2007), as the "spiritual turn.” Roof's (1999) follow-up text reveals similar findings regarding selfidentification. Asking, "Do you consider yourself religious?" and "Do you consider yourself spiritual?" in nonconsecutive places in open-ended interviews (but always in that order) revealed an overall weak association between the two identifications (gamma $=.291$ ). However, among "strong believers" the association was higher (gamma $=.439)$ than among "highly active seekers" (gamma = .196). Other data, including the question "Which is best: to follow the teachings of a church, synagogue or temple, or to think for oneself in matters of religion and trust more one's own experience?" (Roof 1999, 320-321), suggested that those identified as seekers were least likely to rely upon institutional authority or to think that such authority should overrule their own conscience. The response of an Asian American participant who was no longer active in the Methodist Church captured this well:

You can be spiritual without being religious. I think religious ... would be more specific. The faith is more specific, certain doctrines. Spiritual would be general, wider. I think that's how you can be spiritual without being religious. Maybe even religious without being spiritual. Show up for church and go through the motions. (Roof 1993, 78)

Roof's work echoes the highly popular Habits of the Heart (Bellah, Madsen, Sullivan, Swidler and Tipton 1985), which became the second best selling sociological work in history (Yamane 2007). In it the pseudonymous Sheila Larson gave rise to the term "Sheilaism," used by Larson to describe her own faith. Yamane $(2007,183)$ has noted that if Sheila had today's language available to her during the interview, she "surely would have offered up the contemporary mantra, 'I'm spiritual, not religious'."

For the United States, we have an explicit research tradition on the "spiritual" self-identification. Marler and Hadaway (2002) report and discuss a considerable body of studies which have been completed in about a decade before the year 2001. From these studies, we have evidence that there are between $18 \%$ and $20 \%$ who self-identify as being "spiritual, but not religious" (Marler and Hadaway 2002; cf. Streib 2008).

(C) Equinox Publishing Ltd. 2011 
In a more global perspective, including European countries, Houtman's and Aupers' (2007) re-analysis of the huge amount of World Values Survey data $(n=61,352)$ demonstrates a trend to (what they call) a "post-Christian spirituality." The authors present longitudinal results about the spread of people who associate themselves with a spiritual worldview and document this trend over a period of two decades in most of the 14 countries for which they have analyzed the data. Based on a selection of questions regarding the image of God (personal God; some sort of spirit or life force; etc.), New Age affinity, disagreement with traditional Christian beliefs, but simultaneous disagreement with secular rationalism, this re-analysis reveals that France, Great Britain, the Netherlands and Sweden most clearly reveal a pattern of decline of traditional values and religion. Houtman's and Aupers' analysis shows, for the religious fields in the United States and in Germany, a modest (U.S.A.) or recognizable (Germany) longitudinal increase of post-Christian spirituality from 1980 to 2000 . Houtman's and Aupers' research can be understood as opening, on the macrosociological level, the question whether there is a trend to unchurched spirituality also in Europe.

From our Bielefeld-Based Cross-Cultural Study of Deconversion (Streib, Hood, Keller, Csöff and Silver 2009) in which both authors of this article directed teams in Chattanooga and Bielefeld that have worked together in a cooperative transatlantic research project, we have results not only on disaffiliation or deconversion, but also rather surprising results on self-identified "spirituality" (cf. Streib 2008). Note that in Germany there was no research about "spiritual" preference, before we started to ask such questions in 2001 in a pilot study of the Deconversion Project (Streib 2005) and in the study itself (Streib, Hood, Keller et al. 2009; Streib 2008, 2011).

We asked more than a thousand members in a broad variety of religious organizations, and some 130 deconverts, a set of forced-choice questions to assess spiritual/religious self-identification. Table 1 (next page) presents the results.

As Table 1 shows, our results reveal high numbers of people who selfidentify as being "more spiritual than religious": more than $18 \%$ of members in religious organizations in Germany and almost 37\% in the United States. Compared to other studies about spiritual self-identification, our results are somewhat higher, especially for the United States. However, the real surprise are the deconverts: their preference for the "more spiritual than religious" self-identification almost doubles to $36.5 \%$ in Germany and $63.6 \%$ in the United States.

(C) Equinox Publishing Ltd. 2011

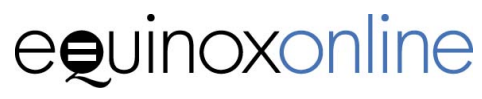


Table 1 Spiritual/Religious Self-Identification of Deconverts and In-Tradition Members in the U.S. and Germany. Source: Bielefeld-Based CrossCultural Study of Deconversion.

Religious/Spiritual Self-Identification

I am more I am more I am equally I am neither religious than spiritual than religious and religious nor Total spiritual religious spiritual spiritual

\begin{tabular}{|c|c|c|c|c|c|}
\hline $\begin{array}{c}\text { In-Tradition } \\
\text { Members }(n=356)\end{array}$ & $43.3 \%$ & $18.3 \%$ & $32.6 \%$ & $5.9 \%$ & $100.0 \%$ \\
\hline Deconverts $(n=52)$ & $19.2 \%$ & $36.5 \%$ & $23.1 \%$ & $21.2 \%$ & $100.0 \%$ \\
\hline $\begin{array}{cc}\text { 岂 } & \text { In-Tradition } \\
\text { 苞 } & \text { Members }(\mathrm{n}=649)\end{array}$ & $10.2 \%$ & $37.0 \%$ & $46.8 \%$ & $6.0 \%$ & $100.0 \%$ \\
\hline Deconverts $(n=66)$ & $6.1 \%$ & $63.6 \%$ & $13.6 \%$ & $16.7 \%$ & $100.0 \%$ \\
\hline
\end{tabular}

For an interpretation of these rather high percentages of "more spiritual than religious" self-identifying deconverts, we need to take into account the variety of ways of exiting religious groups which we refer to as deconversion trajectories. These have been explored by quantitative analysis, and by qualitative interviews. In our sample we have 29 deconverts who have taken a secular exit; they appear to have terminated concern with religious belief altogether. The number of deconverts who exit the field of organized religion, however, is far greater: there are 24 deconverts who have terminated affiliation, but continued practicing their religiosity in private ("privatizing exit"); also there is another group of nine deconverts in our sample who after disaffiliation engaged in what may be called patchwork religion ("heretical exit"). Thus almost two-thirds of the deconverts have left the field of organized religion. However, even those who took secular exits only rarely self-identify as atheists. This finding of ours is consistent with other research on secularists (Kosmin and Keysar 2007). Even in the most unchurched areas of the United States, such as the Northwest, there are no more than 3\% who self-identify as atheists (Keysar 2007). But, despite low scores on self-identified religion, many secularists remain more spiritual than religious (Pasquale 2007). In our study, there are 8 out of 29 secular exiters who self-identify as "more spiritual than religious." This type of "more spiritual atheists" receives growing attention (Schnell and Keenan 2010, 2011; Streib and Klein 2011), and should be more

(C) Equinox Publishing Ltd. 2011 
closely investigated in future research.

The question whether there is an increase in "more spiritual" or "spiritual, but not religious" self-identifications over the last years, suggests we pay attention to some recent survey results. In 2008, the Religionsmonitor (Bertelsmann Foundation) revealed new results which almost match our results in the Deconversion Study for the U.S. sample. The Religionsmonitor has included a self-rating scale for spirituality next to a self-rating scale for religiosity. For the United States, the Religionsmonitor data reveal the following percentages of "more spiritual than religious" respondents (cf. Streib 2008): 25.9\% Christians, 33.3\% Jews, 39.0\% members of other religions, and—surprisingly— $47.8 \%$ religiously not affiliated respondents. The Religionsmonitor also presents new results for Germany: 10.1\% Protestants, 8.7\% Roman Catholics, 5.3\% Protestant in "free churches," and 16.7\% in other Christian traditions, can be identified as "more spiritual." Taken together, 9.3\% members of Christian religious organizations can be identified as being "more spiritual than religious." We can estimate $10 \%$ of Germans who have no religious affiliation at all, but self-identify as being "more spiritual than religious."

We can also refer to the International Social Survey Programme (ISSP) 2008, for which data in the U.S. and in Germany have been collected in the spring and summer of 2008. The questionnaire of this third round of the ISSP survey with a focus on religion has, for the first time, included a set of four questions for the self-identification as religious or spiritual person (for items and frequencies, see Table 2, next page).

The ISSP data also allow an assessment of the spiritual/religious selfidentification in relation to religious affiliation, disaffiliation and nonaffiliation. Table 3 (p.441) presents the results of a cross-tabulation of a constructed variable on affiliation changes since pre-adolescence with the variable for the spiritual/religious self-identification (Table 2). For this cross-tabulation, five groups have been constructed: 1) people who do not report any religious affiliation, neither in the past, nor at present; 2) people who were raised in a religious tradition, but have no current affiliation; 3 ) people not raised in a religion, but currently religiously affiliated; 4) people who have changed their religious tradition; 5) people who have kept the same religious affiliation as the one in which they were raised. While between $40 \%$ and $50 \%$ of the respondents in the U.S. who remain within, or have joined the field of organized religion, self-identify as "equally religious and spiritual," whether they change affiliation or not, we see an increase of self-identifications as "spiritual, but not religious" among respondents

(C) Equinox Publishing Ltd. 2011

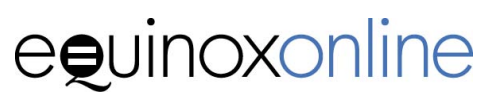


Table 2 Religious/Spiritual Self-Identification in the U.S.A. and Germany. Source: International Social Survey Programme (ISSP) 2008.

What best describes you:

I follow a religion and consider myself to be a spiritual person interested in the sacred or the supernatural.

I follow a religion, but don't consider myself to be a spiritual person interested in the sacred or the supernatural.

I don't follow a religion, but consider myself to be a spiritual person interested in the sacred or the supernatural.

I don't follow a religion and don't consider myself to be a spiritual person interested in the sacred or the supernatural.

Total

$\begin{array}{cc}\text { U.S.A. } & \text { Germany } \\ (\mathrm{n}=1,298) & (\mathrm{n}=1,452)\end{array}$

$40.7 \%$

$9.8 \%$

$23.4 \%$ $30.9 \%$

$24.0 \%$

$11.9 \%$

$47.9 \%$

$100.0 \%$

$100.0 \%$

who change affiliation. In Germany, the large group of respondents who remain within the field of organized religion self-identify as "religious, but not spiritual." So far the ISSP results mainly correspond to the previous research.

The surprising difference comes with the respondents who have no current religious affiliation, either because they were not raised in a religious tradition and did not join one later, or because they have left their preadolescent religious affiliation. This group, as can be expected, self-identify in large part as "neither religious nor spiritual": in Germany, $86.1 \%$ and $75.1 \%$, in the U.S. around $40 \%$. However, $47.5 \%$ stable non-affiliates and $46.7 \%$ disaffiliates in the US- that is, almost every second person outside the organized segment of the religious field—self-identify as "spiritual, but not religious." We see significant cross-cultural differences here: in Germany, the portion of "spiritual but not religious" stable non-affiliates and disaffiliates is only $12.6 \%$ and $16.7 \%$, respectively.

A great portion in the U.S. self-identifies as being "equally religious and spiritual." This could indicate, especially for the US respondents, that religiosity and "spirituality" largely share common ground. This could also

(C) Equinox Publishing Ltd. 2011 
Table 3 Spiritual and Religious Self-Identifications in Groups of Affiliates, Non-Affiliates and Dis-Affiliates in the U.S. and Germany. Source: International Social Survey Programme (ISSP) 2008.

Spiritual/Religious Self-Identification

\begin{tabular}{|c|c|c|c|}
\hline $\begin{array}{l}\text { I follow a } \\
\text { religion, } \\
\text { I am a } \\
\text { spiritual } \\
\text { person }\end{array}$ & $\begin{array}{l}\text { I follow a } \\
\text { religion, I } \\
\text { am not a } \\
\text { spiritual } \\
\text { person }\end{array}$ & $\begin{array}{l}\text { I don't } \\
\text { follow a } \\
\text { religion, } \\
\text { I am a } \\
\text { spiritual } \\
\text { person }\end{array}$ & $\begin{array}{l}\text { I don't } \\
\text { follow a } \\
\text { religion, I } \\
\text { am not a } \\
\text { spiritual } \\
\text { person }\end{array}$ \\
\hline
\end{tabular}

\begin{tabular}{|c|c|c|c|c|c|c|}
\hline$\stackrel{8}{\stackrel{8}{0}}$ & $\begin{array}{l}\text { Stable religious non- } \\
\text { affiliation }\end{array}$ & $.6 \%$ & $.6 \%$ & $12.6 \%$ & $86.1 \%$ & $100 \%$ \\
\hline 苂 & $\begin{array}{l}\text { Disaffiliation, no } \\
\text { current affiliation }\end{array}$ & $1.9 \%$ & $6.2 \%$ & $16.7 \%$ & $75.1 \%$ & $100 \%$ \\
\hline 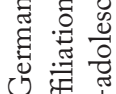 & $\begin{array}{l}\text { New affiliation (none } \\
\text { in past, but current) }\end{array}$ & $3.8 \%$ & $30.8 \%$ & $15.4 \%$ & $50.0 \%$ & $100 \%$ \\
\hline 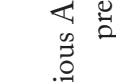 & $\begin{array}{l}\text { Change of religious } \\
\text { affiliation }\end{array}$ & $24.6 \%$ & $41.5 \%$ & $12.3 \%$ & $21.5 \%$ & $100 \%$ \\
\hline 气ี & $\begin{array}{l}\text { Stable religious } \\
\text { affiliation }\end{array}$ & $14.5 \%$ & $47.9 \%$ & $9.5 \%$ & $28.1 \%$ & $100 \%$ \\
\hline$\stackrel{8}{0}$ & $\begin{array}{l}\text { Stable religious non- } \\
\text { affiliation }\end{array}$ & $9.8 \%$ & $1.6 \%$ & $47.5 \%$ & $41.0 \%$ & $100 \%$ \\
\hline ڤ : & $\begin{array}{l}\text { Disaffiliation, no } \\
\text { current affiliation }\end{array}$ & $5.3 \%$ & $7.3 \%$ & $46.7 \%$ & $40.7 \%$ & $100 \%$ \\
\hline 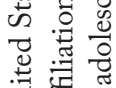 & $\begin{array}{l}\text { New affiliation (none } \\
\text { in past, but current) }\end{array}$ & $46.8 \%$ & $21.3 \%$ & $14.9 \%$ & $17.0 \%$ & $100 \%$ \\
\hline 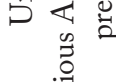 & $\begin{array}{l}\text { Change of religious } \\
\text { affiliation }\end{array}$ & $41.4 \%$ & $22.8 \%$ & $31.5 \%$ & $4.3 \%$ & $100 \%$ \\
\hline בี & $\begin{array}{l}\text { Stable religious } \\
\text { affiliation }\end{array}$ & $48.6 \%$ & $28.1 \%$ & $17.3 \%$ & $6.0 \%$ & $100 \%$ \\
\hline
\end{tabular}

indicate that the "spiritual, but not religious" or "more spiritual than religious" respondents mainly reject institutional or explicit religion, without affecting their search for a transcendent or for the sacred of some sort, which remains religious, if privatized.

This may suggest also an answer to the question why the "more spiritual" preference in the groups of deconverts double. The doubling of self-identified "more spiritual" subjects in the group of deconverts may be due to the

(C) Equinox Publishing Ltd. 2011

\section{equinoxonline}


fact that leaving a tradition involves distance from a church or religious organization. A considerable part of the deconverts is left with no more than their own individual religiosity, but will be reluctant to call this kind of individual religiosity a "religion," because the word "religion" is strongly associated with organization, membership and tradition. Thus, perhaps, self-identified "spirituality" does not mean much more than "religiosity," namely privatized individualized and experience-oriented religiosity.

We conclude for empirical research that we need to continue to develop and improve research designs and measures that allow the investigation of privatized and experience-oriented religion. And, if we do not want to foreclose unchurched research participants, those who oppose religion, or are angry toward God (Exline and Martin 2005), or self-identify as atheists or non-theists, measures should not be restricted to the semantics of traditional religion, but should allow for an indication of invisible (cf. Luckmann 1967) or implicit (Bailey 1997; Schnell 2008; Thomas 2001) religiosity.

If Hood (2006) is right with his assumption that mysticism in contemporary empirical research can be identified by questions that elicit a "spiritual, but not religious" self-identification, contemporary "spirituality" can be identified by scales measuring mysticism (Hood 1975). Hood (2003a) has reviewed several empirical studies using various indices of mysticism. Overall, a clear pattern emerges: spirituality is more closely identified with mystical experience, whereas religion is more closely identified with a specific religious interpretation of this experience. Zinnbauer et al. (1997) used a modified form of Hood's M Scale (unity items only) and found that in their overall sample, self-rated religiousness did not correlate with mystical experience $(r=-.04)$, but self-rated spirituality did $(r=.27, p<.001)$. Furthermore, there was a significant difference between the mean mysticism scores for the "equally spiritual and religious" group and the "spiritual but not religious" group, with the latter scoring significantly higher.

Thus, we can conclude that mystical experience is commonly reported by individuals who identify themselves as "spiritual rather than religious," and by those who identify themselves as "equally religious and spiritual." In other words, there is a mysticism ("spirituality") both within and outside of religious traditions. Perhaps, as Katz (1983) reminds us, there are mystics who, even when struggling against their faith tradition, stay within their traditions. Religious mysticism, for them, is inherently conservative, in this limited sense. For these religious people, belief serves to adequately express their mystical experiences, and their religious rituals facilitate them (Hood 1995). But for some "independent" mystics, spirituality is only constrained

(C) Equinox Publishing Ltd. 2011 
and choked by belief. These independent mystics are those who consider themselves to be spiritual but not religious.

If these people are more willing to identify themselves as "spiritual" than as "religious," it would be a social-scientific oversight to think that they have nothing to do with "religion."We conclude that taking into account a possible commonality between spirituality and religion concerns two levels of reflection that need to be carefully distinguished: 1) the semantics of "spirituality" and "religion" in the self-identification of the respondents, and 2) the conceptualization of 'religion' and 'spirituality' as scientific concepts. The former calls for further research; the latter will be addressed in the rest of this article.

\section{Can "spirituality" be a scientific concept?}

Pargament (1999b; Zinnbauer and Pargament 2005) defines religion as "a search for significance in ways related to the sacred" and spirituality (in almost the same words) as "search for the sacred." When Pargament immediately adds that spirituality is the "most central function of religion" and the "heart and soul of religion" (1999b, 12), we can conclude that religion and spirituality are indeed closely related and intertwined. Both religion and spirituality are defined by the relation to the sacred. The sacred, Zinnbauer and Pargament $(2005,34)$ state, is the "substantive core of both religiousness and spirituality"; the sacred is the specific difference "that distinguishes these phenomena from all others."

The sacred thereby refers not only to God, higher powers and transcendent beings, but to a broad variety of aspects of life: "Virtually any dimension can be perceived as holy, worthy of veneration or reverence" (Zinnbauer and Pargament 2005,34). The critical question of Emmons and Crumpler (1999), in their response to Pargament's 1999 article, namely the question, "Can we leave God out?" has stimulated Pargament to be more explicit. While the sacred, he explains in his reply, is in certain cases "clearly derived from the divine" $(1999 a, 38)$, there are other processes in which "perception of divine-like qualities in objects are not necessarily rooted in beliefs in God." And he goes on to explain that:

for atheists and others as well, it might be useful to think of sacred objects as 'functionally autonomous' from God. The sacred object is no longer directly associated with the divine, however it continues to be imbued with divine-like qualities. (1999a, 39)

We agree with such broad conceptualization, but prefer to identify a vertical and a horizontal dimension of transcendence. The vertical dimension may reference God, but the horizontal need not (Hood, Hill, and

(C) Equinox Publishing Ltd. 2011

\section{equinoxonline}


Spilka 2009, 280-287). Horizontal transcendence may be purely secular (Comte-Sponville 2007; Elkins 2001; Schnell 2009). Many in ecological movements, based upon purely secular scientific assumptions, nevertheless see the self as embedded in a unity larger than itself. "Green" spirituality can be seen as horizontal transcendence (Kalton 2000).

When it comes to clarifying the difference between religion and spirituality, Pargament argues that religion is the broader construct, a "broadband construct" which "encompasses the search for many objects of significance," while "spirituality focuses on the search for one particular object of significance-the sacred" (1999b, 13, cf. Zinnbauer and Pargament 2005, 36). Here, we may find the reason why "significance" is included in the definition of religion, but is left out in the definition of "spirituality." Religion "addresses a wider range of goals, needs, and values than spirituality" (Zinnbauer and Pargament 2005, 37). Pargament's argument goes on that the more that "objects of significance in life are sanctified," the more the difference between "religion" and "spirituality" disappears (1999b, 14). In our reading, Pargament has in mind a model which, for religion, regards the definitional characteristic of "relation to the sacred" as less important, while the "search for significance" serves as its key characteristic. Here we must point to a conceptual problem: on the one hand, the sacred is assumed to be the "substantive core of both religiousness and spirituality"; on the other hand, this characteristic, that the sacred is the core, appears to apply only for spirituality in the full sense, while religion also includes a wide variety of non-sacred (i.e. secular goals).

What we find remarkable, and wish to underscore as potentially helpful insights from Pargament, are the following: first, religion and spirituality are closely related; second, it is the sacred which is "central to both religion and spirituality" $(1999,37)$; third, the sacred thereby is very broadly understood to include sacred objects which need not be associated with God or the divine.

The major question which we raise is this: Why do we need two concepts at all, when their difference is so marginal? Is it not a waste of time and energy to develop special measures of spirituality, if they, as Pargament $(1999 \mathrm{~b}, 8)$ himself notes, "look suspiciously like old measures of religiousness," and add little or no incremental validity to the study of religion? Most measures of spirituality operate empirically as measures of religious experience (Gorsuch and Miller 1999; Hood 2003b; Hood, Hill and Spilka 2009).

In a multi-author article (Hill et al. 2000), "Conceptualizing Religion

(C) Equinox Publishing Ltd. 2011 
and Spirituality," in which also Pargament and Hood are among the co-authors, we find further assertions that religion and spirituality are the same. The authors define both spirituality and religion in exactly the same words, namely as "the feelings, thoughts, experiences, and behaviors that arise from a search for the sacred" (Hill et al. 2000, 66). Because of the identical wording of both definitions, it is in fact questionable whether spirituality and religion have any features distinct enough to suggest two concepts and justify two sets of measures. When, furthermore, the term sacred is defined as referring to "a divine being, divine object, Ultimate Reality, or Ultimate Truth as perceived by the individual," both religion and spirituality are conceptualized rather in the tradition of a substantive definition of religion, but very open in the variety of individual symbolizations. And in regard to these symbolic characteristics, the authors do not propose any difference between religion and spirituality.

The authors, however, suggest a difference between religion and spirituality by ascribing certain additional characteristics only to "religion": first, that only in religion, a potential "search for non-sacred goals" could take place; second, that only religion involves "the means and methods ... of the search for the sacred that receive validation and support from an identifiable group." Here is our critical reply: first, why should the "nonsacred goals," which supposedly are included in religion, occur only in the religious domain and not also in the spiritual domain? The authors provide no argument why spirituality is immune against secondary secular goals. Thus, it is not plausible that secular (or not-yet-sanctified) goals should qualify as characteristics for the construct of religion proper. Second, the assumption that only in religion the search for the sacred receives validation and support from an identifiable group may refer to a specific difference that characterizes a certain type of religion (namely the religion that has become an institution or an organization with legitimacy and tradition). Yet, spirituality may also receive validation and social support, for example, from monasteries or spiritual networks.

For about two decades now we have been witnessing to new developments in the religious field: a growing preference for "spirituality," which may have seeds in the Baby Boomers generation, but which grows and blossoms in mainstream culture after the turn of the century. And we cannot yet see or even predict the decline of such a development. We have also seen considerable attempts to come to terms with this spiritual turn. The new (spirituality) is still treated as the different, and kept separate from religion, or even understood as opposed to religion (Hood 2003b, Hood,

(C) Equinox Publishing Ltd. 2011

\section{equinoxonline}


Hill and Spilka 2009). The time has come for conceptual clarification.

In the scientific study of religion, there is no need to adopt the polarization or opposition between religion and "spirituality" that our research participants may have in mind. It is our duty in the academy to aim at conceptual precision. And we are able to find such precision by considering lines of thought from nineteenth century and early twentieth century sociology, psychology and theology.

\section{The contribution of the classics for understanding "spirituality"}

When James $(1902,72)$ defines "religion" as "feelings, acts, and experiences of individual men in their solitude, so far as they apprehend themselves to stand in relation to whatever they may consider the divine," his definition of religion already embraces and includes "spirituality." Certainly, "spirituality," as it is used today, is not James' term; he, rather, speaks of mysticism and other forms of relation to the divine. But certainly for him, "spirituality" does not stand in contrast with or opposition to religion. On the contrary, James $(1902,77)$ suggests understanding the "godless or quasigodless creeds" which he finds in Emerson or in Buddhism as religionand immediately adds that, for an adequate understanding, the "divine" needs to be understood "very broadly." Consistent with such broad understanding of the divine is a surprisingly broad variety of forms of relation to whatever the individual may consider the divine. The interesting point in the context of our argument is not so much the variety of religious experiences, but the fact that, for James, all of them go by the name religion.

The conclusion, in face of the variety of forms which are all embraced and included in religion, is James' (1902, 927-929) suggested common ground of all religious experience. In our reading of this conclusion of James, we find strong arguments for an inclusion of what we today call "spiritual" experiences in the domain of "religion." Or the other way round: to define "religion" so broadly as to include all so-called "spiritual" experiences.

In Schleiermacher's (1799, 22-23) definition of religion as "intuition and feeling" or, more specifically, as "sensibility and taste for the infinite," we discern another suggestion of including the spiritual quest within the concept of religion. Religion, Schleiermacher $(1799,22)$ says, "wishes to intuit the universe, wishes devoutly to overhear the universe's own manifestations and actions, longs to be grasped and filled by the universe's immediate influences in childlike passivity." Thus, if we want to find religion in research, we have to attend to feelings and intuitions. Religion is not about grasping something, but about being grasped; religion is not a search for

(C) Equinox Publishing Ltd. 2011

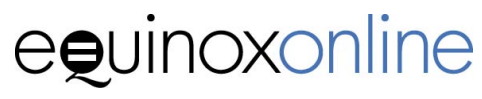


significance, and does not include secular aims, as in Pargament's definition, but a "letting go" and letting oneself be impressed and intuited by an incomprehensible realm: by the "infinite" or the "universe."

Consistently, Hood (1995, 571-576) has emphasized that Schleiermacher's concept of religious feeling has both mystical and numinous characteristics; it is less a search for than a response to the sacred. In a similar fashion, James $(1902,481)$ refers to a sense of "more" that is integral to religious experience. Much of religion is concerned with articulating what this "more" is. James' (often erroneously seen) dismissal of this "more" as mere overbeliefs fails to appreciate that James's insistence was on an empirically-grounded theology of human experience. In a similar fashion, Schleiermacher's "sensibility and taste for the infinite" is a form of consciousness identified with the infinity of God-consciousness which can be elicited by a variety of finite objects, but is always in need of some theological clarification. Here again is more than ample room for the range of experiences which many would treat as "spiritual," but which have classically been acknowledged as the proper domain of religion.

Turning to sociology, we may consider the famous distinction between church and sect, which had some prominence in the sociological discourse of which Weber and Troeltsch were part (see Simmel 1911). The churchsect distinction has become one of the basic tools for understanding religion in sociological terms and for constructing the religious field. Taking a closer look into Weber's (1921) work, we find a distinction between three parties or three actors, rather than between two: not only do the sects with their prophets compete with the churches and their priests; the third party are the magicians. It has been widely ignored (cf. Daiber 2002, 329) that Troeltsch $(1911,1912)$ also talks about three types. But Troeltsch called this third type mysticism.

A general theory of mysticism, in the tradition of Troeltsch, should differentiate even more clearly and incorporate two kinds of mysticisms - that within the church and what Parsons $(1999,141)$ has called "unchurched mysticism." According to both Bouyer (1980) and Troeltsch (1912), one form of mysticism is an inherent tendency to seek personal piety and an emotional realization of a faith within the individual; it serves simply to intensify commitment to a tradition. The other kind of mysticism emerges independent from, or as a reaction to, the church or the sect. In the widest sense, mysticism is simply a demand for an inward appropriation of a direct, inward and present religious experience (Troeltsch 1931, 730). It takes the objective characteristics of its tradition for granted, and either

(C) Equinox Publishing Ltd. 2011

\section{equinoxonline}


supplements them with a profound inwardness, or reacts against them as it demands to bring them back "into the living process" (Troeltsch 1931, 731). Concentrating on the purely interior and emotional side of religious experience, it creates a "spiritual" interpretation of every objective side of religion, so that these kinds of mystics typically stay within their tradition (Katz 1983).

However, Troeltsch also identifies a "narrower, technically concentrated sense" of mysticism $(1931,734)$. This is a mysticism that has become independent in principle from, and is contrasted with, religion. It claims to be the true inner principle of all religious faith. This type of mysticism breaks away from religion, which it disdains. It accepts no constraint or community other than ones that are self-selected and self-realized. This is what many today profess to be "spirituality" as opposed to "religion." It is essentially an unchurched mysticism.

To summarize Troeltsch's legacy: aside from the ideal types of church religion and sect religion, which both, within their realms, may embrace and nurture a kind of mystical inward orientation, Troeltsch identifies mysticism as the type of religion that features religious individualism, develops outside of church and sect, and has no external organization (Daiber 2002, 335). This identification of religious individualism, including mysticism as a third ideal type, was thoughtful, and perhaps ahead of his time. We witness today a global spread of just this kind of religious individualism.

\section{Conclusion: "spirituality" as privatized, experience-oriented religion}

Our conclusions for conceptualization are simple, but, if they are true and would find acceptance among our colleagues, they would change the semantics in the field considerably. Here are our theses. Our first thesis says: Self-identified "spirituality" is (nothing but) religion. Our second thesis says: This "spirituality" is part of religion. The third thesis says: "spirituality" is privatized, experience-oriented religion.

We could use a different adjective for this third thesis and say: "spirituality" is mystical religion - in the sense of Troeltsch's mysticism of the unchurched. The problem with the adjective "mystical" is this: it should clearly and unambiguously specify a differentia specifica. Mysticism, however, refers to a "churched" and an "unchurched" version. Therefore, we think, sociological terms are more helpful.

The conclusion from our three theses is this: there is no necessity for a conceptualization of "spirituality" - the concept of religion is sufficient. In more technical terms: "spirituality" as an emic term needs to be taken

(C) Equinox Publishing Ltd. 2011

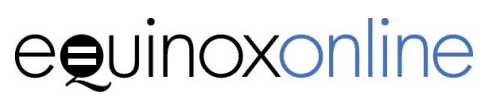




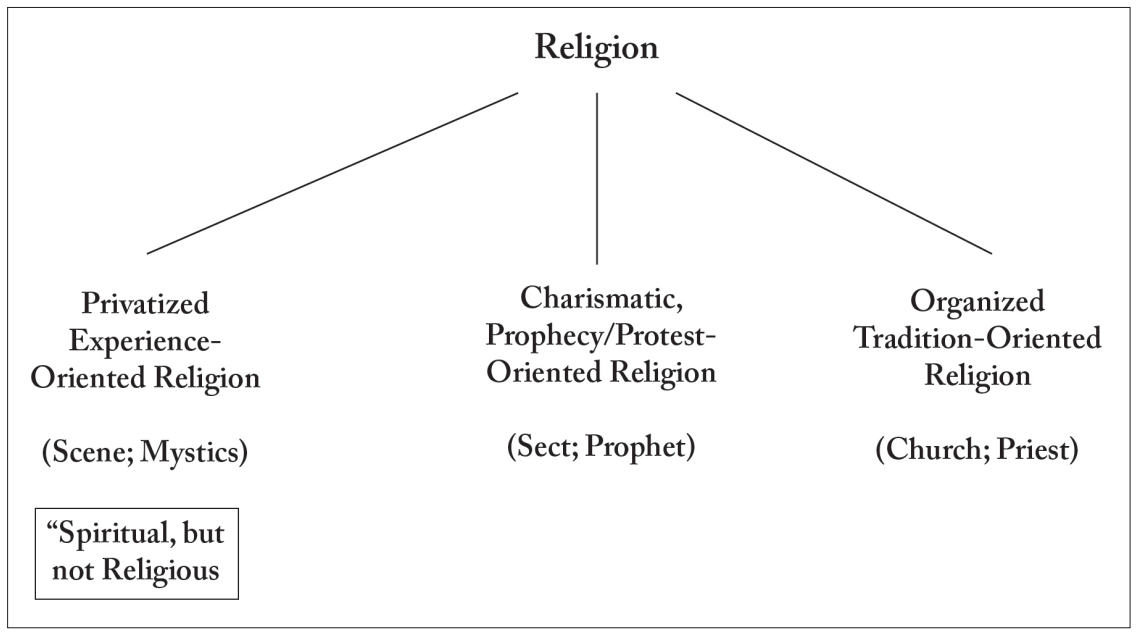

Figure 1. Definition Tree for "Religion" in Respect to Spirituality.

seriously and we need to engage in research that clarifies the semantics of "spirituality" for those who identify themselves as either "more spiritual than religious" or as "spiritual, but not religious." However, as an etic term, "religion" is sufficient; the concept of "spirituality" as an etic term can go.

To be more precise, we propose a definition tree as visualized in Figure 1: "Religion" is the genus proximum. One way of defining different forms that are included in "religion" is to define the differentiae specificae according to sociological aspects: we could use adjectives such as "organized/traditionguided," "charismatic/prophecy-oriented" and "privatized/experience-oriented" to indicate the specific differences. These adjectives may be sufficient for the contemporary religious fields in the United States and Europe.

The conclusion for scientific conceptualization and terminology would thus be the following: it does not make sense to invest time and energy in conceptualizing "spirituality." This term is unnecessary for the scientific discourse and for the conceptualization of etic terms in empirical research. On the contrary, it is a waste of energy to develop parallel concepts, scales and measures. Furthermore, it is confusing to use the terms "religion" and "spirituality" in parallel and interchangeably. And finally, it would be a mistake to replace "religion" with "spirituality," because it is not necessary to re-invent the wheel and cut off a century of conceptual discourse rooted in classical philosophical, theological, and social scientific works.

(C) Equinox Publishing Ltd. 2011 


\section{References}

Bailey, E.I. 1997. Implicit Religion in Contemporary Society. Kampen: Kok.

Bellah, R.N., R. Madsen, W.M. Sullivan, A. Swidler and S. M. Tipton, eds. 1985. Habits of the Heart, revised ed. Berkeley: University of California Press.

Bouyer, L. 1980. "Mysticism: An Essay in the History of the Word." In Understanding Mysticism, edited by R. Woods, 42-55. Garden City, NY: Image.

Comte-Sponville, A. 2007. The Little Book of Atheist Spirituality. Translated by Nancy Huston. New York: Viking Press.

Daiber, K.-F. 2002. "Mysticism: Troeltsch's Third Type of Religious Collectivities." Social Compass 49(3): 329-341. http://dx.doi. org/10.1177/0037768602049003002

Day, J.M. 1991. “Narrative, Psychology and Moral Education.” Journal of the American Psychological Association 46: 167-178.

1994. "Moral Development, Belief and Unbelief: Young Adult Accounts of Religion in the Process of Moral Growth." In Belief and Unbelief. Psychological Perspectives, edited by J. Corveleyn and D. Hutsebaut, 155-173. Amsterdam and Atlanta: Rodopi.

Elkins, D.N. 2001. "Beyond Religion: Toward a Humanistic Spirituality." In The Handbook of Humanistic Psychology: Leading Edges in Theory, Research and Practice, edited by K.J. Schneider, J.T. Bugental and J.F. Pierson, 201-212. Thousand Oaks, CA: Sage Publications.

Emmons, R.A. and C.A. Crumpler. 1999. "Religion and Spirituality? The Roles of Sanctification and the Concept of God." The International Journal for the Psychology of Religion 9(1): 17-24. http://dx.doi.org/10.1207/ s15327582ijpr0901_3

Exline, J.J. and A. Martin. 2005. "Anger Toward God: A New Frontier in Forgiveness Research." In Handbook of Forgiveness, edited by E.I. Worthington, 73-88. New York and London: The Guilford Press.

Gorsuch, R.L. and W.R. Miller. 1999. "Assessing Spirituality.” In Integrating Spirituality Into Treatment: Resources for Practitioners, edited by W.R. Miller, 47-64. Washington: APA. http://dx.doi.org/10.1037/10327-003

Hathaway, W.I., R.W. Hood, L. Miler, R.F. Paloutzian, K.I. Pargament and C.L. Park. 2004. Discussion: Psychology of Religion or Psychology of Religion and Spirituality? Should the Division Include Spirituality in Its Name? Paper for the Annual Meeting of the American Psychological Association, Toronto.

Hill, P.C., K.I. Pargament, R.W. Hood, M.E. McCullough, J.P. Swyers, D.B. Larson, et al. 2000. "Conceptualizing Religion and Spirituality: Points of Commonality, Points of Departure." Journal for the Theory of Social Behaviour 30: 51-77. http://dx.doi.org/10.1111/1468-5914.00119

Hood, R.W. 1975. "The Construction and Preliminary Validation of a Measure of Reported Mystical Experience." Journal for the Scientific Study of Reli-

(C) Equinox Publishing Ltd. 2011 
gion 14: 29-41. http://dx.doi.org/10.2307/1384454

1995. “The Soulful Self of William James.” In The Struggle for Life: A

Companion of William James' The Varieties of Religious Experience, edited by D.W. Capps and J.L. Jacobs, 209-219. West Lafayette, IN: Society for the Scientific Study of Religion.

2003a. "Conceptual and Empirical Consequences of the Unity Thesis." In Mysticism: A Variety of Psychological Perspectives, edited by J.A. Belzen and A. Geels, 17-54. New York: Rodopi.

2003b. "Spirituality and Religion." In Religion: Critical Approaches to Drawing Boundaries between Sacred and Secular, edited by A.L. Greil and D.G. Bromley, 241-264. Amsterdam: Elsevier. http://dx.doi. org/10.1016/S1061-5210(03)10014-X

2006. "The Common Core Thesis in the Study of Mysticism." In Where God and Science Meet: How Brain and Evolutionary Studies Alter our Understanding of Religion, Vol. 3, edited by P. McNamara, 119-138. Westport, CT: Praeger Publishers.

Hood, R.W., P.C. Hill and B. Spilka. 2009. The Psychology of Religion: An Empirical Approach, 4th ed. New York: Guilford Press.

Houtman, D. and S. Aupers. 2007. "The Spiritual Turn and the Decline of Tradition: The Spread of Post-Christian Spirituality in 14 Western Countries, 1981-2000." Journal for the Scientific Study of Religion 46: 305-320. http://dx.doi.org/10.1111/j.1468-5906.2007.00360.x

James, W. 1902. 1944. The Varieties of Religious Experience. A Study in Human Nature. New York: Random House.

Kalton, M.C. 2000. “Green Spirituality: Horizontal Transcendence.” In The Psychology of Mature Spirituality: Integrity, Wisdom, Transcendence, edited by P. Young-Eisendrath and M.E. Miller, 187-200. London: Routledge.

Katz, S.T. 1983. Mysticism and Religious Traditions. Oxford: Oxford University Press.

Keysar, A. 2007. "Who are America's Atheists and Agnostics?" In Secularism and Secularity. Contemporary International Perspectives, edited by B.A. Kosmin and A. Keysar, 33-39. Hartford, CT: Institute for the Study of Secularism in Society and Culture, Trinity College.

Kosmin, B.A. and A. Keysar. 2007. Secularism and Secularity. Contemporary International Perspectives, online at: http://prog.trincoll.edu/ISSSC/ Book/Chapters.asp.

Luckmann, T. 1967. The Invisible Religion: The Problem of Religion in Modern Society. New York: Macmillan.

Marler, P.L. and C.K. Hadaway. 2002. “'Being Religious' or 'Being Spiritual' in America: A Zero-Sum Proposition?” Journal for the Scientific Study of Religion 41: 289-300. http://dx.doi.org/10.1111/1468-5906.00117

Miller, W.R. and C.E. Thoresen. 2003. "Spirituality, Religion and Health-An Emerging Research Field.” American Psychologist 58: 24-35. http:// dx.doi.org/10.1037/0003-066X.58.1.24

(C) Equinox Publishing Ltd. 2011 
Pargament, K.I. 1999a. "The Psychology of Religion and Spirituality? Response to Stifoss-Hanssen, Emmons and Crumpler." The International Journal for the Psychology of Religion 99: 35-43. http://dx.doi.org/10.1207/ s15327582ijpr0901_5

1999b. "The Psychology of Religion and Spirituality? Yes and No." The International Journal for the Psychology of Religion 99: 3-16. http://dx.doi. org/10.1207/s15327582ijpr0901_2

Parsons, W. B. 1999. The Enigma of the Oceanic Feeling: Revisioning the Psychoanalytic Theory of Mysticism. Oxford: Oxford University Press.

Pasquale, F. L. 2007. "The 'Nonreligious' in the American Northwest." Online at: http://prog.trincoll.edu/ISSSC/Book/Chapters.asp, 2008-9-3.

Roof, W.C. 1993. A Generation of Seekers: The Spiritual Journeys of the Baby Boom Generation. San Francisco: Harper \& Row. 1999. Spiritual Marketplace: Baby Boomers and the Remaking of American Religion. Princeton, NJ: Princeton University Press.

Schleiermacher, F. 1799. On Religion. Speeches to its Cultured Despisers. Translated and edited by Richard Crouter. Cambridge, UK: Cambridge University Press, 1996.

Schnell, T. 2008. "Implizite Religiosität: Vielfalt von Lebensbedeutungen in religiösen Ausdrucksformen. "In Individualisierung-SpiritualitätReligion: Transformationsprozesse auf dem religiösen Feld in interdisziplinärer Perspektive, edited by W. Gräb and L. Charbonnier, 83-107. Münster: Lit Verlag, 2009. “The Sources of Meaning and Meaning in Life Questionnaire (SoMe): Relations to Demographics and Well-being." The Journal of Positive Psychology 4: 483-499.

Schnell, T. and W.J.F. Keenan. 2010. "A Trace of Spiritual Atheism.” Paper for the First International Conference of the British Association for the Study of Spirituality, Windsor, May 2010. 2011. "Meaning-Making in an Atheist World." Archive for the Psychology of Religion/Archiv für Religionspsychologie 33: 55-78.

Shafranske, E.P. 1996. "Religious Beliefs, Practices and Affiliations of Clinical Psychologists." In Religion and the Clinical Practice of Psychology, edited by E.P. Shafranske, 149-164. Washington, DC: American Psychological Association. http://dx.doi.org/10.1037/10199-005

Simmel, G. 1911. Verhandlungen des Ersten Deutschen Soziologentages vom 19-22. Oktober 1910 in Frankfurt a.M. Tübingen: Schriften der Deutschen Gesellschaft für Soziologie, I. Serie, Mohr (Paul Siebeck).

Streib, H. 2005. "Research on Life Style, Spirituality and Religious Orientation of Adolescents in Germany." In Religion, Education and Adolescence: International and Empirical Perspectives, edited by L. J. Francis, M. Robbins and J. Astley, 131-163. Cardiff: University of Wales Press.

(C) Equinox Publishing Ltd. 2011

\section{equinoxonline}


2008. "More Spiritual than Religious: Changes in the Religious Field

Require New Approaches." In Lived Religion: conceptual, empirical and practical-theological approaches, edited by H. Streib, A. Dinter and K. Söderblom, 53-67. Leiden: Brill. http://dx.doi.org/10.1163/ ej. $9789004163775 . \mathrm{i}-404.30$

_ . 2011 (in press). "Deconversion." In Oxford Handbook on Religious Conversion, edited by L.R. Rambo and C.E. Farhadian, Oxford: Oxford University Press.

Streib, H., R.W. Wood, B. Keller, R.-M. Csöff and C. Silver. 2009. Deconversion. Qualitative and Quantitative Results from Cross-Cultural Research in Germany and the United States of America. Research in Contemporary Religion 5. Göttingen: Vandenhoeck and Ruprecht.

Streib, H. and C. Klein. 2011. The Spirituality of Atheists, Agnostics and Deconverts. Paper for the Conference of the International Association for the Psychology of Religion (IAPR), Bari, Italy August 2011.

Thomas, G. 2001. Implizite Religion. Theoriegeschichtliche und theoretische Untersuchungen zum Problem ibrer Identifikation. Religion in der Gesellschaft 7. Würzburg: Ergon.

Troeltsch, E. 1912. The Social Teaching of the Christian Churches, Vol. 2. London and New York: George Allen and Unwin; MacMillan 1956. 1911. Das stoisch-christliche Naturrecht und das moderne profane Naturrecht. In Verhandlungen des Ersten Deutschen Soziologentages vom 19-22. Oktober 1910 in Frankfurt a.M., 166-214. Tübingen: Mohr (Paul Siebeck).

Weber, M. 1921. Wirtschaft und Gesellschafft. Grundriß der verstehenden Soziologie, vol 2, chapter 5, "Religionssoziologie," 245-381. Tübingen: J.C.B.Mohr (Paul Siebeck).

Whiteley, J. and Loxley, J. 1980. “A Curriculum for the Development of Character and Community in College Students." In Developmental Counseling and Teaching, edited by L. Erickson and J. Whiteley, 262-297. Monterey: Brooks/Cole.

Yamane, D. 2007. "Introduction: Habits of the Heart at 20." Sociology of Religion 68: 179-187. http://dx.doi.org/10.1093/socrel/68.2.179

Zinnbauer, B.J. and K.I. Pargament. 2005. "Religiousness and Spirituality." In Handbook of the Psychology of Religion and Spirituality, edited by R.F. Paloutzian and C.L. Park, 21-42. New York, London: The Guilford Press.

Zinnbauer, B.J., K.I. Pargament, B. Cole, M.S. Rye, E.M. Butter, T.G. Belavich, et al. 1997. "Religion and Spirituality: Unfuzzying the Fuzzy." Journal for the Scientific Study of Religion 36: 549-564. http://dx.doi. org/10.2307/1387689

(C) Equinox Publishing Ltd. 2011

\section{equinoxonline}


equinoxonline 